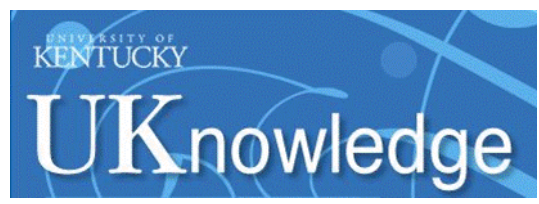

University of Kentucky

UKnowledge

Pharmacology and Nutritional Sciences Faculty

Publications

Pharmacology and Nutritional Sciences

3-13-2017

\title{
Mammary Epithelial Polarity and Macrophage Infiltration
}

Ren Xu

University of Kentucky, ren.xu2010@uky.edu

Follow this and additional works at: https://uknowledge.uky.edu/pharmacol_facpub

Part of the Medical Nutrition Commons, Medical Pharmacology Commons, and the Pharmacology,

Toxicology and Environmental Health Commons

Right click to open a feedback form in a new tab to let us know how this document benefits you.

\section{Repository Citation}

Xu, Ren, "Mammary Epithelial Polarity and Macrophage Infiltration" (2017). Pharmacology and Nutritional Sciences Faculty Publications. 59.

https://uknowledge.uky.edu/pharmacol_facpub/59

This Article is brought to you for free and open access by the Pharmacology and Nutritional Sciences at UKnowledge. It has been accepted for inclusion in Pharmacology and Nutritional Sciences Faculty Publications by an authorized administrator of UKnowledge. For more information, please contact UKnowledge@lsv.uky.edu. 


\section{Mammary Epithelial Polarity and Macrophage Infiltration}

\section{Digital Object Identifier (DOI)}

https://doi.org/10.14800/macrophage.1521

\section{Notes/Citation Information}

Published in Macrophage, v. 4, e1521, p. 1-3.

(C) 2017 The Authors.

Licensed under a Creative Commons Attribution 4.0 International License which allows users including authors of articles to copy and redistribute the material in any medium or format, in addition to remix, transform, and build upon the material for any purpose, even commercially, as long as the author and original source are properly cited or credited. 


\title{
Mammary epithelial polarity and macrophage infiltration
}

\author{
Ren $\mathrm{Xu}^{1,2}$, \\ ${ }^{1}$ Markey Cancer Center, University of Kentucky, Lexington, KY 40536, USA \\ ${ }^{2}$ Department of Pharmacology and Nutritional Sciences, University of Kentucky, Lexington, KY 40536, USA \\ Correspondence: Ren $\mathrm{Xu}$ \\ E-mail: ren.xu2010@uky.edu \\ Received: February 08, 2017 \\ Published online: March 13, 2017
}

\begin{abstract}
Loss of epithelial cell polarity and inflammation are hallmarks of breast cancer development. Although the association between the disruption of tissue polarity and inflammation has been demonstrated, we know little about how these two events are coupled. Using the 3D co-culture model of mammary epithelial cells and monocytes, a recent study reveals a link between disruption of epithelial polarity and monocytes infiltration.
\end{abstract}

Keywords: Inflammation; cell polarity; macrophage infiltration; cancer progression; reactive oxygen species.

To cite this article: Ren Xu. Mammary epithelial polarity and macrophage infiltration. Macrophage 2017; 4: e1521. doi: 10.14800/ Macrophage.1521.

Copyright: (c) 2017 The Authors. Licensed under a Creative Commons Attribution 4.0 International License which allows users including authors of articles to copy and redistribute the material in any medium or format, in addition to remix, transform, and build upon the material for any purpose, even commercially, as long as the author and original source are properly cited or credited.

The establishment and maintenance of epithelial polarity is crucial for the integrity and function of mammary gland. Loss of mammary tissue polarity is associated with cancer development and progression ${ }^{[1,2]}$. Disruption of the polarized epithelial tissue structure occurs at the early stage of breast cancer development. This event is associated with the activation of PI3K-Rac1 signaling pathway and the significant remodeling of tissue microenvironment. Inhibition of the PI3K-Rac1 pathway reprograms the non-polarized breast cancer cells to form polarized spheroids in a $3 \mathrm{D}$ culture model ${ }^{[3,4]}$. Using the $3 \mathrm{D}$ culture assay, we found that disruption of polarized acinar structure is accompanied with increased production of reactive oxygen species (ROS) ${ }^{[5]}$ (Figure 1A). ROS such as hydrogen peroxide, superoxide and the hydroxyl radical, are byproducts of normal metabolism through the electron transport chain. ROS and associated oxidative stress drive cancer development and progression by inducing oxidative damages in DNA, lipids, proteins and other cellular components ${ }^{[6,7]}$, but its function and regulation in the disruption of tissue polarity has not been determined.

Treatment with antioxidant agents can reduce ROS levels and reprogram non-polarized breast cancer cells to form polarized spheroids in 3D culture, indicating that elevation of ROS is necessary to disrupt polarized acinar formation. We also found that introduction of a constitutively activated RAC1 is sufficient to induce ROS generation in mammary epithelial cells ${ }^{[5]}$. Activated RAC1 binds to and forms a complex with NOX1, a homolog of the phagocyte NADPH-oxidase component gp91phox. NOX1 has the capacity to transport electrons across the plasma membrane and to generate superoxide and other downstream ROS. Therefore, RAC1 may increase NOX1-dependent ROS generation. These results suggest that RAC1 is a potential regulator that integrates non-polarized tissue formation and ROS production (Figure 1B). 


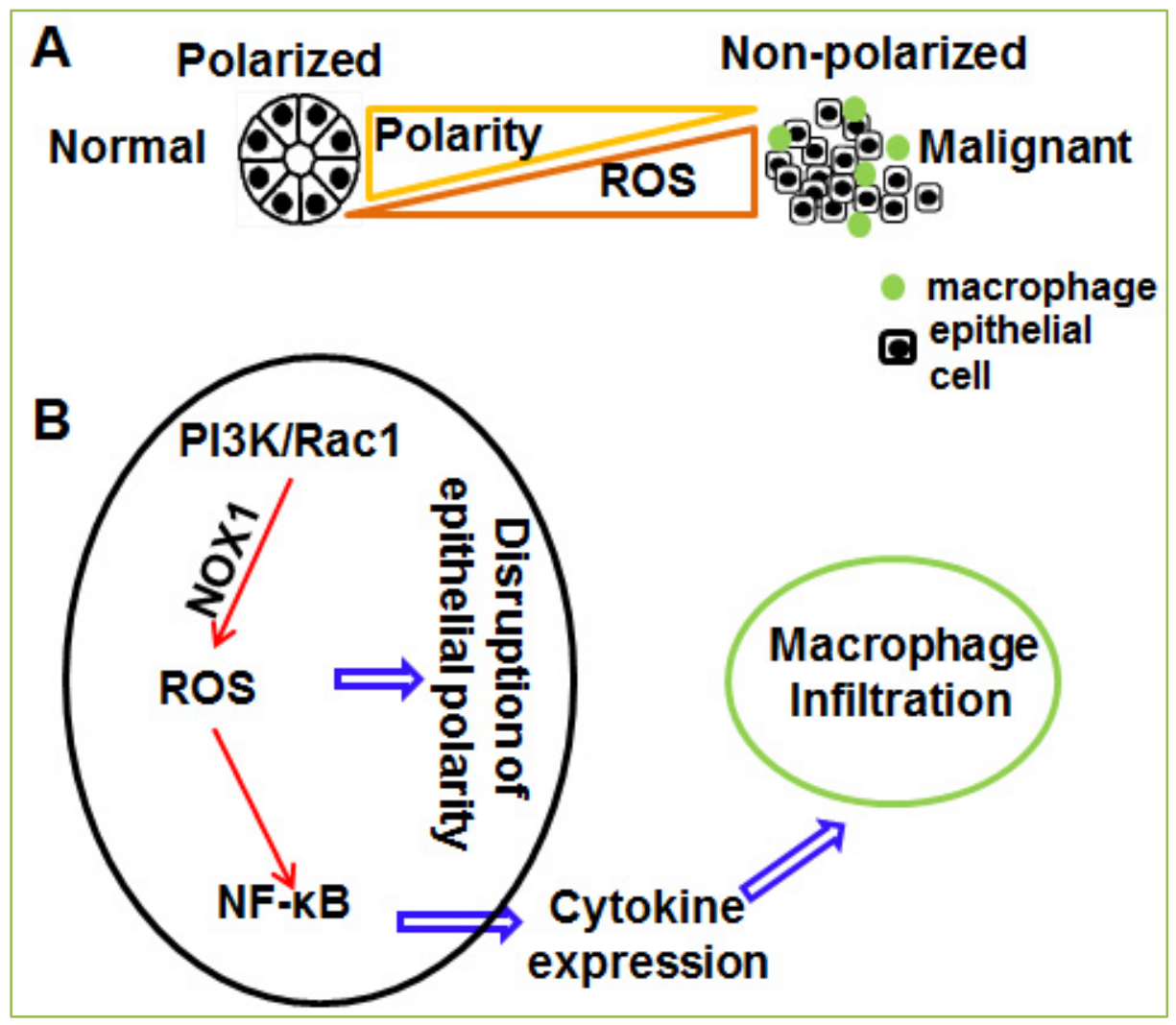

Figure 1. (A) A scheme showing the association of epithelial polarity and ROS production. (B) Summary overview of the signaling pathway in non-polarized breast cancer cells that induces macrophage infiltration.

Macrophages comprise a major stromal component in the tumor microenvironment. The infiltration and differentiation of macrophages determine inflammation in malignant tissue, which in turn promote breast cancer development and progression [8, 9]. Infiltration of tumor-associated macrophages correlates with poor prognosis in breast cancer patients ${ }^{[10,11]}$. Macrophage infiltration occurs at an early stage of breast cancer development [12, 13]; therefore, inhibition of early-stage events such as macrophage infiltration and chronic inflammation may offer a promising strategy to prevent or repress cancer progression. However, it remains a challenge to block cancer-associated macrophage infiltration without disturbing normal function of immune system. Using the 3D co-culture model developed in our group, we show that disruption of mammary tissue polarity leads to monocyte/macrophage infiltration during cancer development ${ }^{[5]}$. In addition, it has been reported that macrophages accumulate around the terminal end buds of mammary glands rather than near the polarized ductal epithelial cells ${ }^{[14,15]}$. Mammary epithelial cells in the terminal end bud are multilayer and non-polarized. These results also suggest that macrophage infiltration is associated with loss of tissue polarity. Interestingly, reducing ROS levels in non-polarized mammary epithelial cells is sufficient to block THP-1 infiltration in 3D culture, indicating that ROS are important mediators of the cancer cell-monocyte interaction (Figure 1B). We show that ROS induce expression of multiple cytokine genes in non-polarized malignant cells ${ }^{[5]}$. These cytokines may promote recruitment and infiltration of monocytes/macrophages in 3D culture.

The NF- $\mathrm{kB}$ pathway is a critical regulator of cytokine expression and macrophage infiltration ${ }^{[16]}$. The gene expression profile analysis and unbiased position weight matrices analysis (PWMA) ${ }^{[17]}$ show that the NF-kB pathway is activated in non-polarized mammary epithelial cells ${ }^{[18]}$. ROS is a well-characterized regulator of the NF- $\kappa \mathrm{B}$ pathway. These results suggest the ROS may modulate monocyte/macrophage infiltration by inducing the NF- $\kappa B$ pathway in mammary epithelial cells (Figure 1B). However, how aberrant activation of the NF- $\mathrm{KB}$ pathway in mammary epithelial cells induces macrophage infiltration still remains to be addressed.

Given the crucial role of ROS in regulating epithelial cell polarity and macrophage infiltration, reducing ROS levels in mammary epithelial cells may be a promising strategy to inhibit cancer-associate inflammation and prevent cancer 
http://www.smartscitech.com/index.php/Macrophage

development and progression.

\section{Conflicting interests}

The authors have declared that no conflict of interests exist.

\section{Acknowledgement}

The study was supported by start-up funding from the Markey Cancer Center and funding support from the American Heart Association (12SDG8600000 to R.X.) and U.S. Department of Defense (W81XWH-15-1-0052 to R.X.).

\section{Abbreviations}

3D: three-dimensional; ROS: reactive oxygen species; PI3K: Phosphoinositide 3-kinase; PWMA: position weight matrices analysis.

\section{References}

1. Muthuswamy SK and Xue B. Cell polarity as a regulator of cancer cell behavior plasticity. Annual review of cell and developmental biology. 2012; 28:599-625.

2. Bissell MJ, Radisky DC, Rizki A, Weaver VM and Petersen OW. The organizing principle: microenvironmental influences in the normal and malignant breast. Differentiation; research in biological diversity. 2002; 70:537-546.

3. Liu H, Radisky DC, Wang F and Bissell MJ. Polarity and proliferation are controlled by distinct signaling pathways downstream of PI3-kinase in breast epithelial tumor cells. The Journal of cell biology. 2004; 164:603-612.

4. Xu R, Spencer VA, Groesser DL and Bissell MJ. Laminin regulates PI3K basal localization and activation to sustain STAT5 activation. Cell cycle. 2010; 9:4315-4322.

5. Li L, Chen J, Xiong G, St Clair DK, Xu W and Xu R. Increased ROS production in non-polarized mammary epithelial cells induces monocyte infiltration in 3D culture. Journal of cell science. 2017; 130(1):190-202.

6. Waris $G$ and Ahsan H. Reactive oxygen species: role in the development of cancer and various chronic conditions. Journal of carcinogenesis. 2006; 5:14.
7. Liu B, Chen Y and St Clair DK. ROS and p53: a versatile partnership. Free radical biology \& medicine. 2008; 44:1529-1535.

8. DeNardo DG and Coussens LM. Inflammation and breast cancer. Balancing immune response: crosstalk between adaptive and innate immune cells during breast cancer progression. Breast cancer research: BCR. 2007; 9:212.

9. Mahmoud SM, Lee AH, Paish EC, Macmillan RD, Ellis IO and Green AR. Tumour-infiltrating macrophages and clinical outcome in breast cancer. Journal of clinical pathology. 2012; 65:159-163.

10. Zhang Y, Cheng S, Zhang M, Zhen L, Pang D, Zhang Q and Li Z. High-infiltration of tumor-associated macrophages predicts unfavorable clinical outcome for node-negative breast cancer. PloS one. 2013; 8:e76147.

11. Medrek C, Ponten F, Jirstrom K and Leandersson K. The presence of tumor associated macrophages in tumor stroma as a prognostic marker for breast cancer patients. BMC cancer. 2012; 12:306.

12. Sharma M, Beck AH, Webster JA, Espinosa I, Montgomery K, Varma S, van de Rijn M, Jensen KC and West RB. Analysis of stromal signatures in the tumor microenvironment of ductal carcinoma in situ. Breast cancer research and treatment. 2010; 123:397-404.

13. Wang HH, Ducatman BS and Eick D. Comparative features of ductal carcinoma in situ and infiltrating ductal carcinoma of the breast on fine-needle aspiration biopsy. American journal of clinical pathology. 1989; 92:736-740.

14. Gouon-Evans V, Rothenberg ME and Pollard JW. Postnatal mammary gland development requires macrophages and eosinophils. Development. 2000; 127:2269-2282.

15. Ingman WV, Wyckoff J, Gouon-Evans V, Condeelis J and Pollard JW. Macrophages promote collagen fibrillogenesis around terminal end buds of the developing mammary gland. Developmental dynamics: an official publication of the American Association of Anatomists. 2006; 235:3222-3229.

16. Karin M. NF-kappaB as a critical link between inflammation and cancer. Cold Spring Harbor perspectives in biology. 2009; 1:a000141.

17. Xiong G, Wang C, Evers BM, Zhou BP and Xu R. RORalpha suppresses breast tumor invasion by inducing SEMA3F expression. Cancer research. 2012; 72:1728-1739.

18. Becker-Weimann S, Xiong G, Furuta S, Han J, Kuhn I, Akavia UD, Pe'er D, Bissell MJ and Xu R. NFkB disrupts tissue polarity in 3D by preventing integration of microenvironmental signals. Oncotarget. 2013; 4:2010-2020. 